\title{
Cultural and linguistic diversity in education as a challenge for teacher training ${ }^{1}$
}

Streszczenie: Poprzez proinkluzywne postawy wobec uczniów z mniejszości oraz uczniów ze specjalnymi potrzebami edukacyjnymi nauczyciele przyczyniają się do ich akceptacji przez społeczność większościową. Nie tylko za granicą, ale także w Republice Słowackiej skład kulturowy populacji uległ zmianie i wciąż się zmienia z powodu migracji. W swoich klasach nauczyciele edukują uczniów z różnych kultur, których język ojczysty różni się od języka, w którym prowadzona jest edukacja. Na podstawie literatury wydaje się, że duża liczba przyszłych oraz aktywnych nauczycieli jest wciąż niewystarczająco przygotowana do pracy z kulturowo i językowo zróżnicowanymi uczniami (Flores and Smith, 2008, za: Vázquez-Montilla Just and Triscari, 2014). Na podstawie analizy wyników PISA 2009 (OECD, 2010c), można stwierdzić, że osiągnięcia uczniów o pochodzeniu imigracyjnym, z kulturowo i językowo odmiennych środowisk, w międzynarodowych testach warunkowane są również ich umiejętnością radzenia sobie z wypełnianiem tego typu testów. W artykule zaprezentowano cele projektu badawczego, skoncentrowanego na uchwyceniu stosunku studentów edukacji przed- i wczesnoszkolnej do zróżnicowania kulturowego i językowego w edukacji.

Słowa kluczowe: zróżnicowanie kulturowe i językowe, edukacja międzykulturowa, postawy nauczycieli

\section{Introduction}

In inclusive education, the teaching profession involves working with diverse groups and also includes working with people having special (educational) needs, as well as with pupils with immigrant background. Four core values connected with teaching and learning have been identified as the basis for the work of all teachers in inclusive education. These include: Respecting

1 The study is the outcome of the VEGA 1/0732/19 project titled Teachers' Attitudes to Diversity in Relation to Selected Characteristics of Teachers, principal investigator Mgr. Mariana Cabanová, PhD. 
the value of pupils' diversity - differences are seen as a source and assets for education; Support for all pupils - teachers set high targets for each pupil; Collaboration - cooperation and teamwork are essential components of each teacher's approach; Personal professional development - teaching is a learning activity and therefore teachers are also responsible for their own lifelong learning (Educating Teachers Towards Inclusion, 2012).

The project focuses mainly on respecting the values of diversity. Respecting the value of pupils' diversity in education is seen as a source and asset to education. We consider important not only the teachers' professional skills enabling them to work with pupils in an inclusive environment, but especially the positive attitudes towards the education of children and pupils with special educational needs in mainstream schools (Chamber, 2013; Cabanová, 2016, 2017), but also different cultures. As per Vedder et al (2006, p. 162), "knowledge and attitudes are closely and mutually interrelated, and both are likely to affect classroom practice". In relation to cultural diversity, such knowledge should be based on the familiarity with other cultures. The available and performed researches and their findings published mainly abroad confirm, that if graduates enter the profession with a positive attitude towards teaching in inclusive classes, it is likely they will be using the successful inclusive practices and continue to apply these practices throughout their professional teacher career (Haugh, 2003). Hachfeld, Hahn. Schroeder, Anders., Stanat and Kunter (2011) state, that very little is known about teachers' beliefs about cultural diversity or about how those beliefs affect immigrant students.

\section{Cultural and linguistic diversity in education}

Availability and much wider possibilities to travel have extensive impact on education system and education contents. Many people see better opportunities for their job and for their families behind the borders of their native country. We see an increasing percentage of migrants in the entire population, particularly in the highly developed countries. According to OECD (2019, p. 78) „immigrants are in the first instance defined as those who are foreign-born, whatever their citizenship at birth. In general, the foreign-born population is substantially larger than the share of foreign nationals. Immigrants' offspring include different categories of people: i.e. they can either be born in their parents' host country to two foreign-born parents; or to a mixed parentage (one foreign-born parent); be foreign-born and arrived as children; or be foreign-born and arrived as adults". 
Multicultural society is currently a reality also in the educational environment in many European countries. For example, Oberhuemer and ColbergSchrader (1999) state, that as early as 1999, children from more than 40 countries from all around the world were educated in 14 kindergartens and school clubs in Munich. Educating in such a diverse setting is a challenge, not only for the school teachers, but also for the entire society. The increasing cultural diversity has a far-reaching impact on education and forces us to reassess the role of schools, as well as teachers in education (OECD, 2013a). The multicultural setting is, in our opinion, one of the significant factors influencing both pre-primary and primary education (see, for example, Venterová, 2018), and it may not always relate to the families of immigrants (Szafrańska, 2018). The right to education obliges countries to ensure that all children have the opportunity to meet their basic educational needs. Respect for other cultures is one of the foundations of an inclusive approach in education. We believe that in education, it is important to constantly strive for mechanisms that would on one hand support the values of the minority culture, on the other hand do not restrain the culture of the majority.

Society, and hence the school, faces a difficult task to assess, or to decide to what extent the diversity of minority cultures can be respected and supported by the majority culture. Although the percentage of migrants in Slovakia is not high, the situation may change due to globalization, thus bringing us closer to the situation at kindergartens and primary schools in Western Europe. Traditionally used symbols and forms of expressions in communication depend on the particular culture the child is growing up in. And this might also be the reason why children after entering pre-school and primary school could show behavior the teachers may find hazardous. That's why we think it is very important and essential for a proper education that the teachers are familiar with the essential behavior patterns of the minority cultures (Mareš, 2013). This applies even though the representation of other cultures in Slovakia's population is not that high.

The reality, however, shows that even though Slovakia might not be amongst the most developed European countries, according to available statistics (OECD, 2010a, 2013a) the number of migrants tripled from $0.78 \%$ in 1985 to $2.41 \%$ in the year 2010.Based on the current situation in the world, we do not think the number of migrants in Slovakia is going to decrease. Divinský and Mihály (2011, pp. 66-67 quoted by Bleh, Šprocha and Vaňo, 2013, pp. 53-54) state, that in case of the increasing standard of living in Slovakia, a larger number of migrants could return with a certain time delay 
and the proportion of foreigners in 2050 could reach up to about $8 \%$ of the total Slovak population.

The situation is also changing in schools. As a result of migration, people are moving also to smaller towns within Slovakia. One of the places they choose to live in, is Banská Bystrica. Kriglerová Gallová (2018, p. 9) states that the most frequent countries of origin of foreigners in Banská Bystrica are the EU countries (such as Czech Republic, Poland, Romania and Germany). In case of the third countries, these mainly include countries of the so-called "former socialist block" - Ukraine, Russia, Serbia, but there is also a relatively large community of citizens from China and Iran. In total, foreigners from 57 countries live in Banská Bystrica. In September 2017, 62 children and pupils with mother tongue other than Slovak, were educated at kindergartens and primary schools in Banská Bystrica. Kriglerová Gallová (2018, pp. 20) states that the greatest problem in their integration, is the language barrier faced by virtually all children who attend the schools. In our opinion, it is essential that people, also in the light of the changing conditions, learn to accept and respect other cultures, and for many, school and education are the place where not only clashes of different cultures, but also the positive attitudes towards other cultures can take place. However, building positive attitudes in pupils is largely influenced by the attitudes of their teachers. Aragona-oung and Sawyer (2018) state, that teachers should understand the role culture plays in the classroom and employ teaching practices that accommodate students from diverse cultural backgrounds.

\section{Cultural and linguistic diversity as a factor influencing pupils' educational success}

Despite the inclusive trend in education, the analysis of pupils' performance in PISA 2009 in relation to their immigrant background tends to indicate that this background may have an impact on pupil's achievement in testing. We assume that pupils with immigrant background also came from a culturally and linguistically different family background. In 2009, more than $10 \%$ of immigrant pupils participated in PISA 2009 (OECD, 2010b) testing performed within the OECD countries. Pupils with an immigrant background score lower in reading literacy testing PISA 2009 (OECD, 2010c) in comparison to non-immigrant pupils. In the analysis of the results achieved in PISA 2009 (OECD, 2010c), pupils are divided into three categories based on their relation to immigrant background, namely: 
- non-immigrant students, born in the country where they participated in PISA 2009 testing, or at least one of the parents was born in the country where the pupil took the test;

- second-generation pupils, represented by pupils born in the country, in which they participated in the testing, but none of the parents was born in the country where the pupil took the PISA 2009 test;

- first-generation pupils, represented by pupils born in another country and not in the country, in which they took the PISA 2009 test.

In general, however, we can conclude that pupils with immigrant background achieved lower scores in PISA 2009 reading literacy testing than pupils who do not have an immigrant background. However, this statement is not a rule, and in several countries even first-generation immigrant pupils have achieved average scores comparable to the national representatives in that country (e.g. New Zealand). As part of the 2009 PISA testing participants, $5 \%$ of the first - and second-generation immigrant pupils were among the most successful in the testing within OECD. In Slovakia, in PISA testing (OECD, 2013b), pupils with immigrant background achieved results comparable to the non-immigrant pupils, but their representation in the Slovak Republic was less than 1\%.In some countries that participated in the testing (e.g. Australia), the first - and even second-generation immigrant pupils were more successful in the reading literacy tests compared to the non-immigrant pupils, and in Israel and Hungary second-generation immigrant pupils scored better than pupils with non-immigrant background.

Based on the available analyzes of the pupils' achievements in the OECD countries (2010c), it appears that, in the reading literacy tests, the secondgeneration pupils scored on average 18 points higher than the first-generation pupils. In countries such as Finland, Austria and Ireland, the first-generation pupils scored up to 40 points less, and in Sweden, Spain, Italy, Greece, the UK and Slovenia, more than 30 points less than the rest. However, this difference in comparison to the first - and second-generation pupils' achievements does not apply to, for example, New Zealand, where the first-generation pupils achieved a higher average score in PISA 2009 than the second-generation pupils.

In general, however, the results indicate, that pupils with immigrant background achieved lower scores in the PISA 2009 reading literacy testing than the pupils with non-immigrant background. Immigrant status is not the only indicator predicting the success, or a failure of an pupil with immigrant background within international testing. In our opinion, family and the family setting, mastering the language of instruction, as well as the immigration 
policies of the individual countries also play an important role. Given the theoretical view of Gažová (2014), we would like to express the hypothesis that the level of success of a pupil with immigrant background may be significantly influenced by the cultural identity, which is considers to be the essential factor relating to the inclusion of minorities into social and cultural life (Gažová, 2014).And one of the reasons for the differences in education achievement may be the inclusion of the tested pupils and their families into one of the basic types of identities created in a multicultural setting.

\section{Conclusion}

We see increasing diversity in schools. Teachers in mainstream schools should be able to educate pupils from different family, cultural and linguistic settings, as well as to fully educate pupils with special educational needs. In the VEGA 1/0732/19 project, we focus on capturing the attitudes and beliefs among the student teachers towards diversity. An understanding of attitudinal beliefs is important because it serves as predictors of teaching behaviors (Flores and Smith, 2008 cited by Vázquez-Montilla, Just and Triscari, 2014).

Due to the population migration, education and in-service teachers, not only in Slovakia, are facing many challenges and questions that they, as well as the entire society, should gradually find answers to. So how to act during education? Insist, that the immigrant learners should respect the culture of the particular country or rather respect their specifics during education? How to set these limits and modify the contents of education? How does the out-of-school multicultural environment change the children entering primary school and their way of behavior within the society? How to educate a child who actually learns the language of instruction directly during the education process? How to prepare teachers for cultural and linguistic diversity in education? The answers to these questions must always be sought not only by the in-service teachers, but also by the policy makers and the designers of the educational content in many countries.

Although the OECD study (2014, pp. 112) states, that teaching in a multicultural or multilingual setting seems not to be an important issue in European countries, but it is a significant concern for Latin American countries and Italy, where more teachers consider this an important need for professional development (46\% of Brazilian teachers, 24\% of Chilean teachers, $27 \%$ of Italian teachers and 33\% of Mexican teachers).Vázquez-Montilla, Just and Triscari (2014, pp. 577) stated, that critical consciousness of attitudes 
and beliefs about the increasing culturally and linguistically diverse student population is necessary for aligning individual beliefs with effective teaching practices. Civitillo, Juang, Schachner (2018, pp. 22) claim, that teacher educators should integrate cultural diversity in a comprehensive curriculum of teacher education.

\section{Bibliography}

Aragona-Young, E. and Sawyer, B.E. 2018. Elementary teachers' beliefs about multicultural education practices. Teachers and Teaching, 24 (5), pp. 465$-486$.

Bleha, B., Šprocha, B. and Vaňo, B. 2013. Prognóza populačného vývoja Slovenskej republiky do roku 2060. Bratislava: INFOSTAT - Inštitút informatiky a štatistiky.

Cabanová, M. 2016. Zmeny spoločnosti ako výzva pre pedagogický výskum detí na prahu vzdelávania.In: Kasáčová, B. and Cabanová, M. eds. Deti na prahu vzdelávania: dôvody a možnosti ich skúmania. Banská Bystrica: Vydavatel'stvo Univerzity Mateja Bela - Belianum, pp. 35-54.

Cabanová, M. 2017. Teachers' opinions on the selected characteristics of children on threshold of education. In: ICERI 2017: 10 ${ }^{\text {th }}$ International conference of education, research and innovation. Madrid: International Academy of Technology, Education and Development (IATED), pp. 1745-1751. Civitillo, S., Juang, L.P. and Schachner, M. K. 2018. Challenging beliefs about cultural diversity in education: a synthesis and critical review of trainings with pre-service teachers. Educational Research Review. 24, pp. 67-83.

Divinský, B. and Mihály, G. 2011. Nové trendy a prognóza pracovnej migrácie v Slovenskej republike do roku 2020 s výhl’adom do roku 2050. Bratislava: Trexima.

Flores, B.B. and Smith, H.L. 2008. Teachers' characteristics and attitudinal beliefs about linguistic and cultural diversity. Bilingual Research Journal. 31, pp. 323-358.

Gažová, V. 2014. Komunikácia kultúr a kultúrna identita. In: Ballay, M., Gabašová, K. and Kudlačáková, V. eds. Minority v substusystéme kultúry. Nitra: UKF, pp. 15-24.

Hachfeld, A., Hahn, A., Schroeder, S., Anders, Y., Stanat, P., and Kunter, M. 2011. Assessing teachers' multicultural and egalitarian beliefs: the teacher cultural beliefs scale. Teaching and Teacher Education. 27, pp. 986-996. 
Kasáčová, B. 2015. Children at the threshold of education and their world. In: ICERI 2015: $8^{\text {th }}$ International conference of education, research and innovation. Madrid: International Academy of Technology, Education and Development (IATED), pp. 1034-1040.

Komora, J. 2013. Poňatie diverzity v školskom prostredí a aspekty pedagogickej diagnostiky v kontexte žiackej diverzity. In: Duchovičová, J. et al. Diverzita $v$ školskej populácii ako objekt pedagogickej vedy. Nitra: UKF, pp. 20-92.

Kriglerová Gallová, E. 2018. Banská Bystrica - mesto pre všetkých? Cudzinci a úloha samosprávy v ich integrácii. Banská Bystrica. Analýza strategických dokumentov a kvalitatívny výskum. Bratislva: CVEK.

Mareš, J. 2013. Pedagogická psychologie. Praha: Portál.

Oberhuemer, P. and Colberg-Schrader, H. 1999. The changing practitioner role in early childhood centres: Multiple shifts and contradictory forces. International Journal of Early Years Education. 7 (3), pp. 249-257.

OECD. 2010a. Trends Shaping Education 2010. Paris: OECD Publishing.

OECD. 2010b. PISA 2009 Results: Overcoming social background: equity in learning opportunities and outcomes (Volume II). Learning outcomes and socio-economic background. Paris: OECD Publishing.

OECD. 2010c. PISA 2009 Results: Reading performance difference between students from single-parent families and those from other types of families: Differences in performance before and after accounting for socio-economic background. In Overcoming Social Background: Equity in Learning Opportunities and Outcomes (Volume II) .

OECD. 2013a. Trends Shaping Education 2013. Paris: OECD Publishing.

OECD. 2013b. PISA 2012 Results: Excellence through Equity (Volume II). Giving every student the chance to succeed. Paris: OECD Publishing.

OECD. 2014. Talis 2013 Results: An international perspective on teaching and learning. Paris: OECD Publishing.

OECD. 2018. International migration outlook 2018. Paris: OECD Publishing.

OECD. 2019. Society at a glance 2019: OECD social indicators. Paris: OECD Publishing.

Szafrańska, A. 2018. (nie)Wiedza nauczycieli mieszkających na pograniczu polsko-czeskim o swoich sąsiadach. Edukacja Międzykulturowa. 2 (9), pp. 195-206 .

Vázquez-Montilla, E., Megan Just, M. and Triscari, R. 2014. Teachers' dispositions and beliefs about cultural and linguistic diversity. Universal Journal of Educational Research. 2 (8), pp. 577-587. 
Vedder, P., Horenczyk, G., Liebkind, K. and Nickmans, G. 2006. Ethno-culturally diverse education settings: problems, challenges and solutions. Educational Research Review. 1, pp. 157-168.

Venterová, L. 2018. Third culture children in the Czech Republic: the influence of parents' cultures on preparing for school. Edukacja Międzykulturowa. 2 (9), pp. 179-192.

Vzdelávanie učitelov k inklúzii.Profil inkluzívneho učitela. 2012. Európska agentúra pre rozvoj špeciálneho vzdelávania. <http://www.europeanagency.org/publications/ereports/te4i-profile/Profile-insert-CS.doc/view> (24.05.2019).

\title{
Cultural and linguistic diversity in education as a challenge for teacher training
}

\begin{abstract}
Through their pro-inclusive attitudes towards learners from minorities and learners with special educational needs, teachers contribute to their acceptance by the majority and intact population. Not only abroad but also in the Slovak Republic, due to migration the cultural composition of the population has been changing. Teachers in their classes educate learners from different cultures, whose mother tongue differs from the language they are being educated in. On the basis of the literature, it appears that a large number of pre-service and in-service teachers still find themselves insufficiently prepared for work with the culturally and linguistically diverse pupils (Flores, Smith 2008 cited by Vázquez-Montilla, Just and Triscari, 2014). On the basis of the analysis of PISA 2009 findings (OECD, 2010c), it appears that the achievements of learners with immigrant background, hence from a culturally and linguistically different environment, within international testing are also influenced by their success in testing. The article comprises a presentation of the aims of a research project focused on capturing attitudes of pre-primary and primary education students towards the cultural and linguistic diversity within education.
\end{abstract}

Keywords: cultural and linguistic diversity, intercultural education, teachers' attitudes 